[This paper is based on an earlier version of chapter 17 of the edited collection The EU Accession to the ECHR. Preferred citation: Georgopoulos, Aris "The EU Accession to the ECHR: An Attempt to Explore Possible Implications in the Area of Public Procurement" in The EU Accession to the ECHR, V. Kosta, N. Skoutaris, V. Tzevelekos (eds.) Hart 2014 pp. 271-290 ]

\title{
The EU Accession to the ECHR: An Attempt to Explore Possible Implications in the Area of Public Procurement
}

\author{
Aris Georgopoulos*
}

\begin{abstract}
The aim of this paper is twofold. First, it tries to map out the areas of potential interplay/interaction between public procurement and human rights. Second, it explores whether the prospective accession of the EU to the ECHR will have concrete consequences in the area of public procurement regulation and practice by creating new pathways/areas of intersections/interaction and/or strengthen existing ones, thus rendering them more attractive. Finally, it will argue that the EU's accession might have a qualitative impact by assisting the shift in the balance between market freedoms and human rights that began with the coming into force of the Treaty of Lisbon and the European Charter of Fundamental Rights.
\end{abstract}

JEL Classification: K1, K12, K19, K23, K3, K30, K33, K39, Z18

Keywords: Public procurement, government contracting, human rights, fundamental rights EU Accession to ECHR, ARIO, legal pluralism, judicial dialogue, EU's autonomy

\section{Introduction}

The field of public procurement has witnessed a remarkable surge of regulatory activity at the European Union (EU) level and consequently at the national level over the last two decades. The practical consequence of this development together with the

\footnotetext{
* Assistant Professor in European and Public Law, University of Nottingham School of Law; Global Governance Fellow, Robert Schuman Centre for Advanced Studies, European University Institute.
} 
fact that public procurement is associated with significant amounts of public spending currently estimated at around 19 per cent of the EU's Gross Domestic Product (GDP) ${ }^{1}$ meant that the latter has become a niche area that has attracted the focused attention of academic researchers and practitioners alike.

The impression that public procurement constitutes a 'self-contained' field of both legal scholarship and practice has been supported not only by a series of regulatory instruments establishing detailed substantive rules but also by a tailormade system of administrative and judicial remedies adopted at the EU level and transposed in the various national jurisdictions (the latter being the main tangible regulatory departure, so far, from the sacrosanct principle of national procedural autonomy). However, in contrast with other niche areas of economic law such as competition law, ${ }^{2}$ the issue of the interaction between public procurement and the area of human rights has attracted much less attention both in academia and in practice. In this context, it is worthwhile wondering how the EU's accession to the European Convention on Human Rights (ECHR) could affect this prima facie 'self-contained' field.

The aim of this chapter is twofold. First, it tries to map out the areas of potential interplay/interaction between public procurement and human rights. Second, it explores whether the prospective accession of the EU to the ECHR will have concrete consequences in the area of public procurement regulation and practice by creating new pathways/areas of intersections/interaction and/or strengthen existing ones, thus rendering them more attractive. Finally, it will argue that the EU's accession might have a qualitative impact by assisting the shift in the balance between market freedoms and human rights that began with the coming into force of the Treaty of Lisbon and the European Charter of Fundamental Rights.

\footnotetext{
The author would like to thank the book editors and particularly Vassilis Tzevelekos for their very pertinent and helpful comments on earlier drafts of the present piece. The usual disclaimer applies.

${ }^{1}$ In 2011 the total expenditure of government at the central, regional and local levels, the service providers of the wider public and utility sectors on works, goods and services was estimated at $€ 2,405.89$ billion (namely 19.0 per cent of EU GDP); see 'Public Procurement Indicators 2011', Brussels, 5 December 2012, 1 and 9 , available at http://ec.europa.eu/internal_market/publicprocurement/docs/modernising_rules/public-procurementindicators-2011_en.pdf.

${ }^{2}$ Regarding the impact the accession of the EU to the ECHR may have in that area, see the contribution by Dr Sanchez Graells in ch 16 in the present volume.
} 
Section II proceeds with the necessary definitions and delimitations, and attempts to conceptualise the relationship between the notion of procurement and human rights - understood as policy tools, objectives and ensemble of specific rights in the context of a given legal order - arguing that the latter sets the limits of the first, but also that the former may constitute one of the means that are available to states for the promotion of human rights policies and objectives. Section III attempts to explain why, to date, the interaction between the two regimes has only been limited as opposed to other areas of economic law; for that reason, it proceeds with a brief comparison between procurement and competition law. Furthermore, it provides a number of examples about how human rights and procurement may intersect within the European context. Section IV contains the core argument of the chapter. After highlighting the fact that, even without the EU's accession to the ECHR, much of what is discussed in the chapter can be claimed before the European Court of Human Rights (ECtHR) in an oblique way-by lodging applications against EU Member States for issues involving EU law-the chapter focuses on the impact that the accession may have on the protection of human rights in the area of procurement law. In that respect, it distinguishes between direct, or tangible impact, on the one hand, and the subtler version of influence the accession will potentially have, consisting in the emergence of a certain human rights 'ethos' in the way procurement performs, on the other hand. Section V sums up the argument and presents some conclusive thoughts.

\section{Public Procurement and Human Rights: Preliminary Clarifications Regarding Nomenclature}

Although there is no official definition of the term 'public procurement', it is generally understood as the process through which the various entities ${ }^{3}$ in the public

\footnotetext{
${ }^{3}$ The EU rules on public procurement use the term 'contracting authorities' to refer collectively to these entities. The term 'contracting authorities' covers the state, regional and local authorities, and the so-called bodies governed by public law, which are bodies that enjoy a special link with the public sector either in the way they are financed, the way their management is appointed or because of the general control that the public sector exercise upon them, or associations formed by one or several of these entities. See Article 1(9) of Directive 2004/18/EC of the European Parliament and of the Council
} 
sector $^{4}$ acquire the goods, services or works they need in order to perform their duties and fulfil their roles. ${ }^{5}$ By and large, public procurement rules are applicable when public authorities resort to the market for finding the solution to their needs. ${ }^{6}$ Public procurement could be further distinguished in public procurement in the narrow sense (stricto sensu) and public procurement lato sensu. The first refers to the process that normally starts with the publication of a contract opportunity and finishes with the award of the contract to a specific economic operator. It is this process that constitutes the focus of the harmonised regime of the European Public Procurement Directives. ${ }^{7}$ Public procurement in the wider sense is synonymous with the notion of 'contracting out'. In other words it not only covers the process that leads to the award of the contract but also includes the stages that follow the award, namely the various stages of contract execution and project management.

Likewise, the concept of human rights can be understood narrowly or widely, at least in the area of legal and judicial practice as well as policy making, depending on the enumeration of specific rights protected at the national, ${ }^{8}$ supranational $^{9}$ and international ${ }^{10}$ levels, the policy choices of the government and equally-if not more-importantly on the intensity of interpretation of these rights by the relevant

of 31 March 2004 on the coordination of procedures for the award of public works contracts, public supply contracts and public service contracts [2004] OJ L134/114 (the Public Sector Procurement Directive). The notion of contracting authorities essentially defines the personal scope of the field of application of the EU public procurement directives.

${ }^{4}$ It should be mentioned that in the field of utilities (water, energy, transport and postal services), the notion of contracting entities also includes private entities that operate on the basis of special or exclusive rights. See Article 2(2)(b) of Directive 2004/17/EC of the European Parliament and of the Council of 31 March 2004 coordinating the procurement procedures of entities operating in the water, energy, transport and postal services sectors [2004] OJ L134/1 (the Utilities Procurement Directive).

${ }^{5}$ For example, they buy stationery and IT equipment for fulfilling their administrative duties, they build bridges and motorways, and they acquire cleaning and security services for their premises.

${ }^{6}$ Public authorities are not obliged to resort to the market for the goods and services they need if they choose to provide them relying on internal resources.

${ }^{7}$ Public Sector Procurement Directive 2004/18/EC (n 3), Utilities Procurement Directive 2004/17/EC (n 4). These two directives are currently subject to a process of amendment. At the time of writing, the 'trialogue' negotiations between the EU Parliament, the Council and the Commission had reached an agreement. The reform proposals also include another substantive legislative instrument, a Directive in the field of concessions. See also Directive 2009/81/EC of the European Parliament and of the Council of 13 July 2009 on the coordination of procedures for the award of certain works contracts, supply contracts and service contracts by contracting authorities or entities in the fields of defence and security, and amending Directives 2004/17/EC and 2004/18/EC [2009] OJ L216/76 (the Defence and Security Procurement Directive).

${ }^{8}$ For example, the Human Rights Act 1998 (Chapter 42) Schedule 1.

${ }^{9}$ For example, the European Charter of Fundamental Rights in the EU legal order.

${ }^{10}$ For example, the Universal Declaration of Human Rights or the ECHR. 
judge. In this way we have a wide spectrum of rights that stretches from rights that are linked with core issues (namely, issues that attract wide-if not universalconsensus) such as the right to life and the prohibition of torture, to other important areas such as social justice, sustainability and the protection of the environment, where support and policy choices vary amongst jurisdictions. Moreover, since all these rights are subject to judicial interpretation, this fact adds a further parameter that affects the intensity of their protection through the establishment of a number of obligations on state authorities reflecting the triptych classification that distinguishes between respect (negative in nature), protection (positive in nature, linked with the idea of due diligence as well as the so-called indirect horizontal effect ${ }^{11}$ (Drittwirkung) of human rights) and fulfilment (reflecting the idea of progressive realisation).

Following the aforementioned observations, it can be argued that the interplay between public procurement and human rights is more evident when the concepts of public procurement and human rights are understood more widely. In particular, when the concept of human rights also refers to general policy choices and priorities set by governments in order to improve or adhere to higher standards linked with the promotion of human welfare (understood under the terms of general or public interest), then the interplay with public procurement is clearer. Human rights are destined to impose limits on the conduct of public authorities. However, outside this obvious dimension, it could also be argued that, in a sense, public procurement can be a vehicle through which the government may facilitate the fulfilment of human rights. In this regard, there are instances where public procurement has been used as an instrument to promote equality and social inclusion, and to correct injustices of the past by reintegrating segregated sections of the society.

For example, the legislation in South Africa uses a preferential system of procurement with the clear aim of reintegrating into society and the mainstream economy large parts of the population that have been subject to unfair racial

\footnotetext{
${ }^{11}$ For a discussion, see P van Dijk and GJH van Hoof, Theory and Practice of the European Convention on Human Rights (The Hague, Martinus Nijhoff, 1998) 22 et seq.
} 
discrimination during the apartheid era ${ }^{12}$ Similarly, in Malaysia the public procurement system ${ }^{13}$ has put in place a number of measures of positive discrimination (preferences and set aside mechanisms) ${ }^{14}$ that aim to raise the economic position of the ethnic Malay part of the population. ${ }^{15}$ Another example is the use of procurement in Northern Ireland as a tool to promote the policy of prohibition of discrimination on the basis of religious and political grounds, and to ensure equal opportunities for all communities by employing the threat of exclusion from public procurement opportunities for economic operators who did not comply with the anti-discrimination rules. ${ }^{16}$ Even at the EU level, the rules on public procurement (which, as mentioned earlier, correspond to the notion of procurement stricto sensu) contain provisions whose objectives are linked with wider human rights considerations such as the integration of people with disabilities to the labour market. ${ }^{17}$

\section{Public Procurement and Human Rights in the European}

\section{Context: Limited But Possible Interaction}

\footnotetext{
${ }^{12}$ Preferential Procurement Policy Framework Act 5 of 2000 and Preferential Procurement Policy Framework Regulations of 2011. P Bolton, 'The Regulatory Framework for Public Procurement in South Africa' in G Quinot and S Arrowsmith (eds), Public Procurement Regulation in Africa (Cambridge, Cambridge University Press, 2013); P Bolton, 'An Analysis of the Preferential Procurement Legislation of South Africa' (2007) 16(1) Public Procurement Law Review 36; G Quinot and P Bolton, 'Social Policies in Procurement and the Government Procurement Agreement: A Perspective from South Africa' in S Arrowsmith and $\mathrm{R}$ Anderson (eds), The WTO Regime on Government Procurement: Recent Developments and Challenges Ahead (Cambridge, Cambridge University Press, 2011); D Letchmiah, 'The Process of Public Sector Procurement in South Africa' (1999) 8(1) Public Procurement Law Review 15.

${ }^{13} \mathrm{C}$ McCrudden and S Gross, "WTO Government Procurement Rules and the Local Dynamics of Procurement Policies: A Malaysian Case Study' (2006) 17(1) European Journal of International Law 155,168 et seq.

${ }^{14}$ Set aside mechanisms effectively reserve certain public procurement contracts — often identified by value thresholds - for a specifically designated group or groups of people.

${ }^{15}$ Malaysia has three main ethnic groups: Malay, Chinese and Indian. The Malay ethnic group is the majority, but in the years before independence was the poorest of the three. The policy of positive discrimination in favour of the Malay majority has its origin post-independence in Article 153 of the Federal Constitution of Malaysia.

${ }^{16}$ Fair Employment and Treatment Order 1998, Order 3162 (NI 21). For an analysis of the regime, see C McCrudden, Buying Social Justice: Equality, Government Procurement, and Legal Change (Oxford, Oxford University Press, 2007) 305 et seq.

${ }^{17}$ See Article 19 and recital 28 of the Public Sector Procurement Directive.
} 
When public procurement and human rights are considered in their narrower sense and in the European context by reference to their respective regulatory frameworks, namely on the one hand the EU public procurement rules-including implementing national legislations - and the EU Charter of Fundamental Rights together with the ECHR on the other, it is observed that, by contrast to other niche areas of economic law, for example, competition law, ${ }^{18}$ the interaction both at the level of legal practice and academic study has been more scarce. Why is that?

It is argued that, although the EU competition rules and EU public procurement rules share the same ultimate goals, namely the attainment and preservation of the internal market, in the case of EU competition law, the focus of the rules and in particular the architecture of enforcement is substantially different from those in EU public procurement law.

First, in the case of competition law, the focus of the regulatory framework falls by and large on the conduct of private natural or legal persons. In other words, the main provisions of EU competition law, namely Articles $101^{19}$ and $102^{20}$ of the Treaty on the Functioning of the European Union (TFEU) were included in primary EU law precisely because the European legislator believed that the so-called four freedom provisions ${ }^{21}$ — whose main focus is the prohibition of measures that are likely to create obstacles or distortions in the internal market as a result of state actionswas not sufficient to deal with the risk of fragmentation of the internal market posed by the conduct of private actors. On the other hand, the public procurement legal

\footnotetext{
${ }^{18}$ See, for example, Compagnie des Gaz de Pétrole Primagaz v France, App No 29613/08 (2010); Canal Plus v France, App No 29408/08 (2010); A Menarini Diagnostics SRL v Italy, App No 43509/08 (2011); Case C-374/87 Orkem v Commission [1989] ECR 3283; Case C-46/87 Hoechst AG and others $v$ Commission [1989] ECR 2859. See also indicatively W Wils, 'The Increased Level of EU Antitrust Fines, Judicial Review, and the European Convention on Human Rights' (2010) 33(1) World Competition 5; OB Vincents, 'The Application of EC Competition Law and the European Convention on Human Rights' (2006) 12 European Competition Law Review 693; E Ameye, 'The Interplay between Human Rights and Competition Law in the EU' (2004) volume 25 issue6 European Competition Law Review, 332-41.

${ }^{19}$ Prohibiting agreements between undertakings, decisions by associations of undertakings and concerted practices which may affect intra-EU trade and have as their object or effect the prevention, restriction or distortion of competition in the internal market. The focus of the provision is on the conduct of two or more undertakings/actors.

${ }^{20}$ Prohibiting undertakings from abusing their dominant position in a given market. The focus of the provision is on the unilateral conduct of the dominant undertaking.

${ }^{21}$ Articles 34 (free movement of goods), 45 and 49 (free movement of people), 56 (free movement of services) and 63 (free movement of capital) TFEU.
} 
framework can trace its origins to the fundamental economic freedom provisions, which, as mentioned above, are concerned primarily with obstacles to trade in the internal market linked with the conduct of public/state actors (contracting authorities more specifically in this case) and establish specific obligations on contracting authorities and corresponding rights for economic operators participating in public procurement.

In addition, the architecture of enforcement of EU competition law is characterised by the dominant role of centralised enforcement carried out by the European Commission and the National Competition Authorities of the EU Member States (NCAs) ${ }^{22}$ who have wide investigatory ${ }^{23}$ and adjudicative powers that can encroach upon the rights enshrined in the European Convention on Human Rights (ECHR) (for example, Article 6). ${ }^{24}$ In this regard, the arsenal of the enforcement of competition law includes fines of a punitive nature ${ }^{25}$ and increasingly significant criminal sanctions for natural persons. ${ }^{26}$

However, in the case of the EU public procurement enforcement system, the dynamics are quite different. It could be argued that this is due to the development of a detailed and sophisticated system of judicial remedies ${ }^{27}$ established at the EU level

\footnotetext{
${ }^{22}$ This trait of the system has not been changed by the decentralisation effected by the 'Modernisation Regulation' (Council Regulation 1/2003/EC of 16 December 2002 on the implementation of the rules on competition laid down in Articles 81 and 82 of the Treaty [2003] OJ L 1), in the sense that the same 'centralised' architecture of enforcement is also replicated at the national level.

${ }^{23}$ Including wide powers of inspection of office and even of private premises (Articles 20 and 21 Regulation 1/2003).

${ }^{24}$ Senator Lines GmbH v Austria, Belgium, Denmark, Finland, France, Germany, Greece, Ireland, Italy, Luxembourg, the Netherlands, Portugal, Spain, Sweden and the United Kingdom, App No 56672/00 (2004).

${ }^{25}$ Regarding the punitive nature of such measures, see by analogy Engel and others $v$ The Netherlands, Judgment of 8 June 1976 [81]. Article 23(2) of Regulation 1/2003/EC provides that the Commission may impose fines up to 10 per cent of the total annual turnover of the undertaking.

${ }^{26}$ Not at the EU level yet, but in a number of EU Member States. See, for example, s 188 of the Enterprise Act 2002 establishing a cartel offence (as amended by s 47 of the Enterprise and Regulatory Reform Act of 2013) and s 190 of the Enterprise Act 2002 establishing a penalty of imprisonment for those guilty of the aforementioned offence.

${ }^{27}$ Council Directive 89/665/EEC of 21 December 1989 on the coordination of the laws, regulations and administrative provisions relating to the application of review procedures to the award of public supply and public works contracts [1989] OJ L 395 (the Remedies Directive) and Council Directive 92/13/EC of 25 February 1992 coordinating the laws, regulations and administrative provisions relating to the application of Community rules on the procurement procedures of entities operating in the water, energy, transport and telecommunications sectors [1992] OJ L 76 (the Utilities Remedies Directive) as amended by Directive 2007/66/EC of the European Parliament and of the Council of 11 December
} 
but implemented at the national level. This means that a lot of the enforcement takes place in a diffused, decentralised manner mainly as a result of the initiative of the aggrieved economic operator before national courts without raising the (same type of) concerns observed in the context of EU competition law enforcement. The Commission may also have a role through the general procedure of Article 258 TFEU, but this is clearly secondary since the Commission uses it mainly in order to address systemic failures in the application of public procurement rules in a Member State rather than as a means to provide relief to an aggrieved contractor. Moreover, in this type of intervention, the Commission has a very specific role, namely that of the pursuer, whereas the adjudicative role is entrusted to the Court of Justice of the European Union (CJEU). This is a completely different set-up from the one in the case of competition law where the Commission acts - at a first level at least - as investigator, prosecutor and judge.

Nevertheless, despite the previous observations, it is argued that there are conceivable situations or instances where the regimes of procurement law and human rights may intersect in the European context. In other words, it is possible for human rights, including, more specifically, the ECHR, to provide a pathway for the protection of an individual's rights in the field of public procurement. For example, it is possible in some jurisdictions that economic operators who bid for procurement contracts whose value is below the procurement thresholds - and as a result not subject to either the substantive or remedy rules of EU public procurement - to have virtually no remedy to challenge the decisions of the contracting authority. Moreover, in such situations, even if EU rights are at stake, ${ }^{28}$ because the usefulness of the mechanism of preliminary reference relies in practice on the willingness of the national courts to make use of it (de facto lack of automaticity in the reference process despite the legal obligation stipulated in Article 267 (3) TFEU), and because there are occasions where the national courts demonstrate reluctance to make preliminary

2007 amending Council Directives 89/665/EEC and 92/13/EEC with regard to improving the effectiveness of review procedures concerning the award of public contracts [2007] OJ L 335.

${ }^{28}$ In principle, contracts below the EU procurement thresholds which may be of 'cross-border' interest are subject to the general principles of EU law (non-discrimination, equal treatment, transparency) even if they fall outside the field of application of the EU public procurement directives. See in particular Advocate General Sharpston's Opinion in Case C-195/04 Commission v Finland [2007] ECR I-3353. 
reference to the CJEU, ${ }^{29}$ the ECtHR could provide a parallel pathway for the protection of aggrieved parties. This possibility could also extend post-accession, either against the EU directly or before it, indirectly, by requesting that an EU Member State be held accountable for a situation linked with powers it has transferred ${ }^{30}$ to the EU.

Another example could refer to a case where an economic operator is excluded by a procurement procedure pursuant to Article 45 of the Public Sector Directive because he or she has been convicted in another country by a judgment which has the force of res judicata for an offence concerning his or her professional conduct, but he or she argues that the standard of due process-in the jurisdiction where he or she was convicted-had been disregarded.

Likewise, it is possible in the context of a procurement process for issues of intellectual property to arise. This is common in the case of procurements that are complex, for example, when the drafting of specifications is rather difficult or when there are no existing solutions in the market. This is the case in the context of procurement procedures-like the 'competitive dialogue ${ }^{31}$ or the 'negotiated procedures' - that allow some level of interaction between the contracting authorities and the economic operators during the procurement process. This means that the final new solution may have elements stemming from the ideas of different candidates. ${ }^{32}$ In such a case, the ECtHR could also provide a pathway for the protection of intellectual property rights under the ambit of Article 1 of Protocol 1 of the ECHR. ${ }^{33}$ By the same

\footnotetext{
${ }^{29}$ It should be remembered that the preliminary reference procedure aims to provide assistance to the national judge in the interpretation of EU law. This means that even if the parties in a dispute before the national court make suggestions for the need of a preliminary reference, the national judge is not bound in any way to act.

${ }^{30}$ M\&Co v Germany, App No 13258/87 (admissibility) EComHR, 9 February 1990.

${ }^{31} \mathrm{P}$ Telles, 'Competitive Dialogue: Should the Rules be Fine-Tuned to Facilitate Innovation?' in C Risvig Hansen, C Tvarn $\varnothing$ and G Skovgaard Ølykke (eds), EU Procurement Directives: Modernisation, Growth and Innovation: Discussions on the 2011 Proposals for Public Procurement Directives (Copenhagen, Djøf Forlag, 2012).

${ }^{32}$ The opportunity for intellectual property issues to arise is expected to increase with the proposal of the innovation partnership procedure. Article 29 of the Proposal for a Directive of the European Council and of the Council on Public Procurement COM (2011) 896 final, 2011/0438 (COD), Brussels, 20 December 2011.

${ }^{33}$ For example, see $A D v$ The Netherlands, App No 21962/93 (1994) (admissibility decision); Melnychuk v Ukraine, App No 28743/03 (2005) (admissibility decision).
} 
token, the ECHR could protect the legitimate expectations ${ }^{34}$ of a contractor whose procurement contract has been (unlawfully) cancelled by the contracting authority.

The proposition that the ECtHR could provide an additional-or rather parallel-pathway for the protection of aggrieved parties in the context of public procurement is supported by the fact that there have been cases in the area of public procurement that reached the Strasbourg Court, such as Tinnelly \& Sons Ltd and others $v$ United Kingdom ${ }^{35}$ and ITC $v$ Malta. ${ }^{36}$ The rather old Tinnelly case raises issues of access to justice as well as of denial of the opportunity for the applicants to bid for a contract on discriminatory grounds related to their religious beliefs. The case is interesting not only as a specimen that prima facie confirms the possibility of using the ECHR as a pathway to protection in the context of public procurement, but also because it provides perhaps an indication as to why that pathway has not been used more widely. Tinnnelly used the domestic remedies that were available before the establishment of the comprehensive remedies system introduced with the Remedies Directive. ${ }^{37}$ In other words, this case took place in a considerably weaker environment of judicial protection. ${ }^{38}$ These observations are further supported by the case of ITC, which, likewise, was brought before the ECtHR in a domestic regulatory environment

\footnotetext{
${ }^{34}$ Maltzan and others $v$ Germany, App Nos 71916/01, 71917/01 and 10260/02 (2005) (admissibility decision).

${ }^{35}$ Tinnelly \& Sons Ltd and others and McElduff and others v United Kingdom, App No 20390/92 (1998) 27 EHRR 249

${ }^{36}$ ITC Ltd v Malta, App No 2629/06 (2007).

${ }^{37}$ The transposition of the Remedies Directive in this case (works) took effect on 21 December 1991. Tinnelly has begun the process of complaints at the national level in 1985 and the final national decision was issued on 3 December 1991. It should be remembered that the procurement remedies are only available for public procurement contracts that fall under the field of application of the substantive procurement directives (namely provided that they are above the applicable value thresholds). It is not clear if the contract in Tinnelly was above those thresholds. However, even if we assume that the contract opportunity was below these thresholds, the judicial protection of Tinnelly at the national level would have been enhanced because of the 'spillover' effect that the establishment of a specialised system of procurement rules (including the remedies system) had in the application of what could be called traditional pre-existing remedies. See also the next footnote.

${ }^{38}$ The UK until the transposition of the Remedies Directives did not have any special remedies in the area of public procurement. In fact, public procurement disputes were considered not to demonstrate any 'public' features that warranted the availability of judicial review proceedings, but rather were considered to be part of private law - a view whose validity was contested in the literature at the time; see in particular S Arrowsmith, 'Enforcing the EC Public Procurement Rules: The Remedies System in England and Wales' (1992) 2 Public Procurement Law Review 92; S Arrowsmith, 'Judicial Review and the Contractual Power of Public Authorities’ (1990) 106 Law Quarterly Review 277.
} 
before Malta's accession to the EU and thus before the creation of a comprehensive system of procurement remedies in Malta. ${ }^{39}$

The above analysis shows that even without looking at the prospective accession of the EU to the ECHR, the Strasbourg pathway for the protection of individual's rights in the context of public procurement has been pertinent, but underused. Then how and to what extent - if at all—will this 'self-contained' field of economic law and policy be affected by a future accession of the EU to the ECHR? We will attempt to address this question in the next section.

\section{Public Procurement and Human Rights after the EU's Accession to the ECHR}

It is beyond any doubt that the accession of the EU to the ECHR will not simply be an event of great symbolic importance, but it will also pose certain challenging questions regarding the de jure constitutional co-habitation of the two judicial powerhouses in Europe. Although the existing de facto relationship is characterised by an element of comity on the basis of the criteria set by the Bosphorus ${ }^{40}$ jurisprudence, and although it is difficult to imagine a post-accession order where the CJEU would not be, formally at least, ${ }^{41}$ subordinated to Strasbourg, it is argued that the last two observations do not prejudge either the real type ${ }^{42}$ or the intensity ${ }^{43}$ of the relationship post-accession. With this in mind, one can hypothesise that the new institutional,

\footnotetext{
${ }^{39}$ Interestingly, ITC $v$ Malta on the one hand strengthens the argument that the ECHR pathway is stronger as an option in the event of a lack of EU rules on remedies, but on the other hand the lack of substantive rules on procurement limits the usefulness of the ECHR pathway, because as the ECtHR stated in the same decision, 'Article 6(1) of the Convention is not aimed at creating new substantive rights without a legal basis in the Contracting State, but at providing procedural protection of rights already recognised in domestic law'.

${ }^{40}$ Bosphorus Hava Yollarl Turizm ve Ticaret Anonim Şirketi v Ireland, App No 45036/98 (2005) 42 EHRR 1. This judgment established the presumption that the EU offers equivalent standards of protection to those of the ECHR and, for that reason, the Strasbourg Court refrained from reviewing the compatibility of EU law with the ECHR.

${ }^{41}$ Regarding the future of the Bosphorus presumption, see the contribution by O De Schutter in ch 12 of the present volume.

${ }^{42}$ Parity between the two courts or subordination of the CJEU to the jurisdiction of the ECtHR.

${ }^{43}$ Intensive review or deference (including the degree and conditionalities of deference) of the ECtHR towards the CJEU.
} 
vertical structure and also the dynamics that will be created may lead to a recalibration of the institutional balance.

On that basis, it is argued that the accession of the EU to the ECHR may indeed have a bearing on the area of public procurement and in fact in two possible ways: one tangible and one subtler. Yet, before exploring these two ways further, it is important to clarify that, theoretically, the ECHR could have played and may still play a role in EU public procurement before the EU's accession. This could apply not only against the conduct of EU Member States stemming from purely national legislation and practices, but also for Member State conduct that originates in and gives effect to rules and practices established at the EU level. In other words, Member States are responsible for the conduct of/linked to the participation to international organisations in which they are members, including the EU. This was the case in Matthews, ${ }^{44}$ for instance, concerning EU primary law, but also in a number of other cases stemming from the implementation of EU law at the national level, such as the aforementioned Bosphorus case or more recently the Michaud jurisprudence. ${ }^{45}$ That said, the argument could be that, substance-wise, no major change will be brought about by the EU accession to the ECHR. If there is an important change, this is that individuals will be allowed to bring their claim directly against the EU (and its Member States), whereas now they can only accuse it in an oblique way, via its Member States-and this is only if the Bosphorus presumption is not satisfied or the state is found to exercise discretion ${ }^{46}$ in the way in which it will implement EU law in its domestic system. Yet this is mainly a question of allocation of responsibility (although such allocation will be hindered by the co-respondent mechanism) and accountability ratione personae. The substance of the claims shall be the same both before and after the accession.

Returning to the ways in which the EU's accession to the ECHR may be relevant to EU public procurement, it is submitted that first of all, this may happen in cases where the EU acts as the contracting authority (through its institutions or agencies). This is what we called earlier as the more obvious/tangible area of

\footnotetext{
${ }^{44}$ Matthews v United Kingdom, Series A 24833/94 (1999) 28 EHRR 36.

${ }^{45}$ Michaud v France, App No 12323/11 (2012).

${ }^{46}$ Bosphorus (n 40) [147]-[148]; and Michaud (n 46) [103].
} 
accession impact. We can illustrate this by making reference to few scenarios/examples.

\section{A. Potential for Tangible Impact}

First, we can refer to the example where the EU acting in the area of Common Security and Defence Policy is involved in a peacekeeping mission outside the EU's geographical area and uses the services of a Private Military and Security Company (PMSC) after a procurement process. The use of PMSCs for the discharge of police and security services in the context of peace-making, peacekeeping missions ${ }^{47}$ is a growing trend that raises a number of important questions such as the human rights obligations of the contractor, as well as the responsibility of the contracting authority. ${ }^{48}$ The same is true when the EU directly or through the Member States uses PMSCs for the discharge of illegal immigration detention facilities within the EU's geographical area. It is submitted that the accession of the EU to the ECHR will potentially open the pathway of the ECtHR to victims and other aggrieved parties from actions or omissions of the contractor against the EU itself, ${ }^{49}$ which is an issue that of course raises technical questions of attribution, extraterritoriality and the obligation to demonstrate diligence that do not fall within the limited scope of the present study.

Second, one can contemplate situations where the relevant EU body that carries out the procurement is not subject to the full jurisdiction of the EU courts. This

\footnotetext{
${ }^{47}$ In fact, in almost all the range of the missions foreseen in Article 43 TEU: 'joint disarmament operations, humanitarian and rescue tasks, military advice and assistance tasks, conflict prevention and peace-keeping tasks, tasks of combat forces in crisis management, including peace-making and postconflict stabilisation'.

${ }^{48}$ For an analysis of these issues, see the Priv-War report, 'Priv-War Recommendations for EU Regulatory Action in the Field of Private Military and Security Companies and their Services', submitted before the EU Commission in spring 2011, available at http://priv-war.eu/wordpress/wp-content/uploads/2013/03/Priv-War_Recommendations-FINAL-.pdf.

${ }^{49}$ The issue of human rights obligations of economic operators in the context of public service outsourcing has arisen at the national level. For example, in $Y$ v Birmingham City Council [2007] UKHL 27, the UK Supreme Court examined whether a private care home when providing accommodation and care to a resident, pursuant to arrangements made with a local authority, is performing 'functions of a public nature' and as a result is subject to the application of the ECHR through the Human Rights Act. The Court answered this by majority of 3:2 negatively. The UK Parliament responded with a statutory measure that restored the balance by extending the application of the Human Rights Act to private entities engaged in the delivery of care home services. It is argued that had the UK Parliament not intervened, the matter could have reached the ECtHR.
} 
may be the case, for example, where the EU body or agency is established under Title $\mathrm{V}$ of the Treaty on European Union (TEU) regarding the Common Foreign and Security Policy. According to Article 24(1) subpara. 2 TEU and Article 275 TFEU, the CJEU does not have jurisdiction with respect to provisions of the CFSP in principle. It can only review the legality of decisions providing for 'restrictive measures' against natural or legal persons adopted by the Council under the CFSP framework. According to Article 215(1) TFEU, the concept of 'restrictive measures' covers measures that relate to the 'interruption or reduction, in part or completely, of economic and financial relations'. Procurement decisions do not seem to fall under the notion of 'restrictive measures' and therefore it seems that these do not fall under the jurisdiction of the EU courts.

For example, the European Defence Agency (EDA) has been established under the $\mathrm{CFSP}^{50}$ provisions of the TEU. The EDA is subject to the authority of the Council of the EU and, according to Article 42(3) subpara2 TEU, is active in the field of defence capabilities development, research, acquisition and armaments. One may think of a situation where the EDA acts on behalf of the EU as contracting authority for the development or the acquisition of common defence assets for use in EU defence and security operations. ${ }^{51}$ Based on the above analysis, the procurement decisions of the EDA will not be subject to the review of EU courts ${ }^{52}$ and therefore potential aggrieved economic operators will in effect be deprived of access to justice or an effective remedy. Although today this scenario could theoretically trigger an indirect pathway to Strasbourg for the aggrieved economic operators through the responsibility of Member States for the conduct of the international organisation to

\footnotetext{
${ }^{50}$ Council Joint Decision 2004/551/CFSP of 12 July 2004 on the establishment of the European Defence Agency [2004] OJ L 245/17.

${ }^{51}$ See the initiative to promote the European defence industrial base as a necessary component of the CFSP, Commission Communication COM(2013) 542 final, 'Towards a more competitive and efficient defence and security sector'.

${ }^{52}$ For a detailed analysis of the procurement rules of the EDA, see B Heuninckx, 'The Law of Collaborative Defence Procurement Through International Organisations in the European Union', $\mathrm{PhD}$ Thesis (University of Nottingham, 2011) 177 et seq; A Georgopoulos, 'The New European Defence Agency: Major Development or Fig Leaf' (2005) 14(2) Public Procurement Law Review 103; A Georgopoulos, 'The European Defence Agency's Code of Conduct for Armament Acquisitions: A Case of Paramnesia?' (2006) 15(2) Public Procurement Law Review 55.
} 
which they belong (here the EU), post-accession, a direct route to the ECtHR against the EU itself could be established.

This would also be the case if the procurement of the common defence assets is entrusted to another international organisation that also has limited or no review mechanisms. This is not simply a hypothesis since the other major international organisation in the field of collaborative defence procurement and project management in Europe is the Organisation for Joint Armament Cooperation (better known by its French acronym 'OCCAR'), which has been established by six EU Member States. ${ }^{53}$ Although it has a distinct international legal personality from the EU, because of its expertise and European character, OCCAR has been deemed even by the European legislator as a plausible candidate for acting as an agent in the procurement of collaborative projects in the EU. ${ }^{54}$ However, it becomes clear by looking at OCCAR's rules that the procurement decisions are only subject to an internal two-stage review. ${ }^{55}$ In particular, the complaints of aggrieved economic operators are heard at a first instance by the Director of the OCCAR Executive Administration (OCCAR-EA) and, if need be, by the OCCAR's Board of Supervisors (BoS) at a second instance. ${ }^{56}$ Neither the decision of the Director OCCAR-EA or that of the BoS is subject to judicial review. ${ }^{57}$ It is self-evident that this wholly internal complaint process lacks the necessary guarantees of independence and impartiality and therefore falls short of the standards required by the ECHR. Although, as such, the EU is not a member of OCCAR, in the post-accession environment, the EU's failure to ensure that the decisions of the international organisation entrusted (on the basis of contractual links established in the sphere of international law) with the procurement of the common EU defence assets are subject to an independent and impartial review could pave the way to Strasbourg. An oblique avenue already exists, since one could accuse the common Member States of the EU and OCCAR that have

\footnotetext{
${ }^{53}$ OCCAR was initially established by France, Germany, Italy and the UK. Belgium and Spain joined later. However, there are more Member States and third countries that participate in one or more of the OCCAR-run collaborative programmes.

${ }_{55}^{54}$ See, for example, Article 25(2) of Council Joint Decision 2004/551/CFSP.

55 OCCAR Management Procedures 5 Annex I, available at www.occar.int/media/raw/OMP5_Contract_Placement_Issue3_170609new.pdf.

${ }^{56}$ The $\mathrm{BoS}$ is an an organ composed of representatives of OCCAR's signatory Member States.

${ }^{57}$ Heuninckx (n 52) 232 et seq.
} 
transferred powers to the latter organisation. Furthermore, although this may raise delicate questions of attribution, one could envisage that the same indirect scheme will also apply for holding the EU accountable when it is contracting out to OCCAR. Any other conclusion would lead to an unacceptably convenient way for the EU to limit its responsibility under the ECHR by 'delegating' tasks to international organisations who are not signatories to the ECHR.

Third, it can be observed that even in the case of institutions, agencies or other bodies of the EU whose procurement decisions in principle fall under the jurisdiction of the EU courts, the EU's accession to the ECHR might have an impact. ${ }^{58}$ If one examines the jurisprudence of the General Court (GC, the competent EU court to hear actions of natural or legal persons against acts of EU bodies) and that of the CJEU (which provides the appeal jurisdiction against GC judgments) with regard to the liability of EU bodies in the context of procurement, it becomes clear that the EU courts seem to adopt a very lenient approach.

For example, in Alfastar Benelux $v$ Council, ${ }^{59}$ the applicant successfully challenged an award decision on the basis of inadequate reasoning in the relevant decision. Alfastar Benelux then claimed damages for the loss of the public contract. The GC rejected the claim because of what, in its eyes, constituted an apparent lack of a causal link between the unlawful conduct (in this case the inadequate reasoning of the award decision) and the alleged damage (in this case the loss of the contract). Furthermore, the GC ruled that it could not examine the pleas for manifest error of assessment based on the available evidence (which the GC found to be inadequate). ${ }^{60}$ Although the rejection of the claim of damages in this case referred to loss of chance, it is not clear whether the Court would have reached a different conclusion had the applicant also claimed damages for the costs of participating in the process. In any case, it is obvious that a number of interesting questions are raised that concern loss

\footnotetext{
${ }^{58}$ It should be mentioned at this point that the procurement process for bodies or agencies that are financed by the EU budget follow the rules contained in the Regulation (EU, EURATOM) No 966/2012 of the European Council and of the Council on the Financial Rules applicable to the general budget of the Union and repealing Council Regulation (EC, EURATOM) 1605/2002. It is submitted that the procurement rules contained in this Regulation (Tile V) are largely based on the rules of the EU Procurement Directives.

${ }^{59}$ Case T-57/09 Alfastar Benelux v Council of the European Union [2011] ECR II-368.

60 ibid [51].
} 
of property, manque à gagner (loss of prospective economic gain), as well as the issue of causality ${ }^{61}$ between unlawful conduct and property rights, which are central to the jurisprudence of the ECtHR - that could be called upon to exercise jurisdiction.

The picture of the GC's lenient approach towards EU bodies to the detriment of the rights of economic operators is further elucidated by Evropaiki Dynamiki v European Investment Bank (EIB). ${ }^{62}$ In this case the applicant successfully sought the annulment of the EIB's award decision and also supplemented its action with a claim for damages. Interesting contextual points in this case are the fact that the contract was to be completed before or soon after the decision of the GC, which meant that the annulment of the award decision would constitute a moral victory for the applicant, but not much else. Moreover, the applicant explicitly mentioned-as a general comment about its previous experience of the effectiveness of judicial protection against the actions of EU bodies in the field of procurement that also highlights the importance of the claim for damages in this case - that successful annulment actions that it had lodged in the past against procurement decisions of EU institutions were not followed up in a satisfactory manner by the relevant EU bodies, ${ }^{63}$ which apparently raises an issue of effectiveness in terms of judicial protection and implementation of case law by the administration, falling under Article 6 ECHR. ${ }^{64}$ Despite all this, the GC rejected the claim for damages because, according to the latter, the applicant did not manage to establish a causal link between the contested (unlawful) decision and the damage. ${ }^{65}$ Furthermore the GC stated in effect that it would have been impossible anyway to establish the causal link because the EIB did not have any obligation to sign the contract with the winning bidder. ${ }^{66}$

\footnotetext{
${ }^{61}$ See, for instance, Önyeryildiz v Turkey, App No 48939/99 (2004) 41 EHRR 325 [135]; and Varnima Corporation International SA v Greece, App No 48906/66 (2009) [41].

${ }^{62}$ Case T-461/08 Evropaiki Dynamiki v European Investment Bank (EIB) [2011] ECR II-6367.

63 ibid [61].

${ }^{64}$ Hornsby v Greece, App No 18357/91 (1998) [40]-[45].

${ }^{65}$ ibid [212].

${ }^{66}$ ibid [211]: 'in any event, even if it were to be accepted that the applicant's tender ought to have been placed first and that the applicant should therefore have been awarded the contract, that would not have obliged the EIB to sign the framework contract with the applicant. Indeed, there is no principle or rule applicable to the EIB's tendering procedures which requires it to sign the relevant contract with the person designated as the contractor at the conclusion of the tendering procedure'.
} 
It is submitted that the impact of the decision in this case-given that due to the factual background of the case, the only 'effective' remedy in this case was the action for damages, but also due to the aforementioned parts of the legal reasoning of the GC which seem extremely problematic_-raises questions as to whether in cases like this one there is in fact access to justice and whether the available remedies are indeed effective. Furthermore, it is argued that the duty of compliance with a set of procedural rules - which can be quite prescriptive at times-on the part of the contracting authority gives rise to legitimate expectations of participating economic operators not only regarding compliance but also vis-a-vis the expected logical outcome/result of this procedural compliance. Furthermore, it should be pointed out that this decision provides a very problematic message to EU bodies that leads directly to what could be considered a systemic 'moral hazard'. Although the analysis of all the aspects of the case fall beyond the purposes of this chapter, it suffices to note that the EIB infringed most of the fundamental rules of the procurement process, yet this epitome of flagrant violation of procurement rules attracted merely the proverbial slap on the wrist by the GC, which of course could de facto incentivise EU bodies to continue to disregard procurement rules. ${ }^{67}$

Of course, the ECtHR cannot act as a fourth degree jurisdiction and rule on the legality in terms of procurement law of the relevant practice of the EU and its Member States. Nor is its role or its jurisdiction to remove the discrepancies that appear to exist between the level of judicial protection that economic operators are afforded depending on whether their procurement law rights are infringed by national or by EU contracting authorities. Instead, the ECtHR has jurisdiction to review whether there is in fact access to justice, whether effective remedies are available and whether the standards of fairness are met, as well as whether state and EU authorities comply with judicial decisions. In this regard, it can be observed that the ECtHR tends to adopt a deferential approach in the intensity of the review of proportionality

\footnotetext{
${ }^{67}$ Moreover, the judgment runs contrary to the logic of the principle of effectiveness in judicial protection of EU rights in the European legal order. It is reminded that in Factortame (Case C-213/89 $R v$ Secretary of State for Transport ex parte Factortame Ltd and others [1990] ECR I-2433), the prospect of a meaningless victory-comparable in principle with the empty victory of Evropaiki Dynamiki - in the main proceedings led the CJEU to demand the setting aside of a rule of constitutional significance in the UK - namely the lack of the possibility to orderinterim relief against the Crown.
} 
of national rules and practices-provided that certain minimum standards are observed - in the sense that it does not try to superimpose a higher standard, but rather it uses the national standards that exist in the given legal order as a point of reference.

With this in mind, it is argued that the expected standards of protection of the procurement law rights of economic operators in the EU legal order are expressed by the European legislator in the tailor-made system of procurement remedies that was created with the enactment of the Remedies Directives. ${ }^{68}$ The fact that these Directives are addressed to the Member States and not the EU institutions and agencies is of no consequence for the identification of the appropriate EU standards by the ECtHR, particularly in the context of the professed unity of the EU legal order after the Treaty of Lisbon. The EU legislator established this tailor-made regime as a response to the poor standard of judicial protection witnessed in comparable cases such as Evropaiki Dynamiki v EIB at the national level. Thus, it can be argued that the Remedies Directives constitutes a statement of the expected standards for the protection of economic operators involved in procurement processes in the EU. There is no logical explanation as to why the rights of the same economic operators should be subject to lower standards of protection when procurement rule violations are committed by EU bodies. This argument is supported by the fact that the substantive procurement rules of the Financial Regulation 966/2012/EU, EURATOM-the instrument that governs the procurement of EU institutions and agencies financed by the EU budget - correspond largely to those of the EU public procurement Directives. Thus, after the EU accession to the ECHR, the Strasbourg pathway will be open for economic operators in such cases. Furthermore, it is believed that the mere

\footnotetext{
${ }^{68}$ See in this regard recital 7 of Directive 89/665/EC: 'Whereas in certain Member States the absence of effective remedies or inadequacy of existing remedies deter Community undertakings from submitting tenders in the Member State in which the contracting authority is established'; see also recital 3 of Directive 2007/66/EC: 'Consultations of the interested parties ... have revealed a certain number of weaknesses in the review mechanisms in the Member States ... As a result of these weaknesses, the [review] mechanisms ... do not always make it possible to ensure compliance with Community law, especially at a time when infringements can still be corrected. Consequently, the guarantees of transparency and non-discrimination ... should be strengthened to ensure that the Community as a whole fully benefit from the positive effects of the modernisation and simplification of the rules on public procurement ... [the rules] should therefore be amended by adding the essential clarifications which will allow the results intended by the Community legislature to be attained.'
} 
availability of this option may function as the Sword of Damocles over the shoulders of the EU courts, which might feel compelled to correct the discrepancy on their own motion.

In addition, a more recent case of the CJEU revealed another instance where the involvement of the ECtHR could be contemplated. In Commission v Systran SA, ${ }^{69}$ the CJEU reversed, on appeal, the decision of the $\mathrm{GC}^{70}$ which ordered the Commission to pay to Systran lump-sum damages for infringement of copyright and disclosure of know-how following an invitation to tender. According to the CJEU, the GC had concluded erroneously that the dispute was of a non-contractual nature and as a result infringed the rules that demarcate its jurisdiction (negative jurisdiction). ${ }^{71}$ The case raises a number of interesting issues regarding the delimitation of EU courts' jurisdiction vis-a-vis their national counterparts in the area of the contractual liability of the EU. However, for the purposes of this chapter, it also highlights the risk that economic operators face in such a case, namely to be left without any judicial protection if all the courts that potentially could be involved issue negative jurisdiction rulings, thus leaving economic operators in a judicial limbo. It should be remembered that the CJEU's judgment in the present case was binding on the GC, but it was not binding on the national courts in Luxembourg, which had jurisdiction to hear disputes arising from the relevant contract. ${ }^{72}$ Although in principle situations like this should be resolved within the EU legal order on the basis of sincere cooperation between all the actors involved ${ }^{73}$-in this case the national and EU courts-if economic operators are found in such a limbo of lack of effective remedy and access to justice, they may seek the ECtHR's protection. Before the accession of the EU to the ECHR, such recourse could be limited against Member States directly (insofar as their failure to provide remedies at the national level is concerned) and indirectly (as members of the EU for the failures of the latter to provide an effective remedy at the EU level). However, post-accession to the ECHR, economic operators could be in a

\footnotetext{
${ }^{69}$ Case C-103/11 P Commission v Systran SA and Systran Luxembourg, Judgment of 18 April 2013 (not yet reported).

${ }^{70}$ Case T-19/07 Systran SA and Systran Luxembourg v Commission [2010] ECR II-6083.

${ }^{71}$ In particular Articles 256(1), 268 and 274 TFEU.

${ }^{72}$ Systran (n 69) [12].

${ }^{73}$ See Article 4(3) TFEU; Case 294/83 Les Verts v Parliament [1986] ECR 1339 [23]; Case C-50/00 P Unión de Pequeños Agricultores v Council of the European Union [2002] ECR 6677 [62].
} 
position to lodge an application against the EU directly, which, under certain conditions, may be placed in the position of a co-respondent together with its Member States.

\section{B. Potential for Subtle Impact}

Finally, apart from the instances mentioned above, where the EU accession to the ECHR could potentially have a tangible impact in the area of public procurement, there are also other cases where accession may have a subtler impact.

One such example refers to the use of fair trade standards by the contracting authorities. It is important to remember that EU Member States have a positive obligation to respect, protect and fulfil the right enshrined under Article 4 ECHR, namely the prohibition of slavery and forced labour. ${ }^{74}$ This area is of particular importance in the context of the globalised market economy and has continued to attract attention, not least because of reports revealing the appalling conditions that employees, sometimes children, have to endure in the so-called 'sweatshops' around the world. Although Member States are in a position to respect and protect human rights in their own territories, arguably they may also be under due diligence obligations not to condone practices violating these rights that take place outside their territory. ${ }^{75}$ The examination of the existence of the due diligence obligation and the limit of the latter, especially in the case of extraterritoriality, is beyond the scope of the present chapter. ${ }^{76}$ However, it suffices to note that due diligence is an obligation

\footnotetext{
${ }^{74}$ The ECHR does not contain a definition of the term 'forced or compulsory labour'. Instead, it uses as a working definition, the one stipulated in Article 2 of the ILO Convention 29 concerning forced or compulsory labour. Article 2 reads: 'forced or compulsory labour shall mean all work or service which is exacted from any person under the menace of any penalty and for which the said person has not offered himself voluntarily'. Furthermore, the ECtHR adopts a wide interpretation of the both the notion of forced or compulsory labour. See Van der Mussele v Belgium, Series A No 70 (1983); Graziani-Weiss v Austria, App No 31950/06 (2011); Stummer v Austria, App No 37452/02 (2011) 54 EHRR 369; CN and Vv France, App No 67724/09 (2012); Siliadin v France, App No 73316/01 (2005) 43 EHRR 287.

${ }^{75}$ The possibility of using procurement by states as a means to achieve results beyond their own jurisdiction is termed by McCrudden as outward links of procurement. These outward links are of particular importance in the era of globalised markets. See McCrudden (n 16) 93 et seq.

${ }^{76}$ In that respect, see the paper by $\mathrm{V}$ Tzevelekos, examining how due diligence imposes an obligation for states to exercise jurisdiction over their own nationals when they operate abroad and break human rights, but also, more generally, how states are obliged to demonstrate diligence every time they are effectively linked to a situation raising issues of human rights protection. V Tzevelekos, 'In Search of
} 
of means in the sense that Member States have discretion in choosing the relevant methods/means to achieve the intended objective, ie, the protection of human rights. One of these possible means is the adoption of fair trade policies/preferences in the context of public procurement. For example, public procurement authorities could require ${ }^{77}$ economic operators to abide by certain standards regarding the employment conditions of the workforce that will be involved in the delivery of the procured goods or services. This requirement for compliance could be set as a condition for participation in the procurement process - as part of the so-called 'selection criteria' in the sense that economic operators who do not comply with these standards cannot participate in the procurement process — or as part of the 'contract award criteria' namely the criteria used to identify the winning tender-or as part of the 'contractual conditions' - the conditions that concern the performance of the contract. It could also be included as a ground for exclusion if, for example, a contractor has been convicted of or has been involved in ${ }^{78}$ using forced labour.

Looking at the aforementioned options, it should be noted that they may have a different impact in the procurement process. In particular, the first option, namely the inclusion of the fair trade conditionality at the stage of selection, is connected with the 'general conduct' of the economic operator in the sense that it requires these standards to be followed by the latter in general, ie, in all its economic operations. The same is true for option four, namely the exclusion of the economic operator in the event of previous conviction/involvement. By contrast, the second and third options focus on the conduct of the economic co-operator in the delivery of the specific procurement contract. Consequently, an economic operator who normally does not comply with these standards can decide to do so in the case of a specific procurement opportunity in order to participate in a specific procurement process. Therefore, one key difference between options one and four on the one hand and options two and three on the other is that the use of the former may lead to a reduction of the number

\footnotetext{
Alternative Solutions: Can the State of Origin be Held Internationally Responsible for Investors' Human Rights Abuses which are Not Attributable to it?' (2010) 35 Brooklyn Journal of International Law 155.

${ }^{77}$ This could reflect wider governmental policies or be based on the initiative of the public authority.

${ }^{78}$ The proving the involvement in ways other than a prior conviction will raise significant evidentiary issues.
} 
of eligible economic operators - and equally to a reduction of competition. By contrast, options two and three do not lead a priori to a reduction of competition in the procurement process. However, as we will see later, options one and four may be arguably more successful in effecting the due diligence obligation by creating more powerful incentives for economic operators to comply with the intended standards.

When Member States consider the options/means that they have at their disposal in order to protect and implement the rights enshrined in the ECHR, they also have to consider the extent to which these are compatible with other obligations that arise under EU law. These policy decisions are subject to the scrutiny of the CJEU, which is competent to review whether the consequences of the latter disproportionately encroach on EU obligations. Looking at the case of the use of procurement as a means to offer protection under Article 4 ECHR, the question that arises is whether this is allowed as a matter of principle and, if so, to what extent. The answer has been provided recently by the CJEU in Commission v The Netherlands. ${ }^{79}$ The case involved the supply and management of dispensing machines for hot drinks (and the supply of other relevant products such as coffee, tea etc). One of the main points of the action of the European Commission was that a requirement imposed by the contracting authority (The province of North Holland) for the use of fair trade criteria constituted a violation of the EU procurement rules. The CJEU accepted the possibility of the use of fair trade criteria in public procurement, but subject to certain conditions. In particular, these fair trade considerations can be used as part of the award criteria provided that they are clear, precise and unequivocal, and are linked with the subject matter of the contract at hand ${ }^{80}$ This means that these fair trade considerations cannot refer to the tenderer's general purchasing policy or other matters of corporate social responsibility in general as part of the assessment of the technical capacity of the tenderer; in other words, the CJEU seems to limit the possibility of fair trade considerations as part of the 'selection criteria'.

It is submitted that the CJEU seems to have adopted a position that is based on a balance of proportionality in the sense that it tried to accommodate fair trade-related

\footnotetext{
${ }^{79}$ Case C-368/10 Commission v The Netherlands, Judgment of 10 May 2012 ECLI:EU:C:2012:284.

${ }^{80}$ ibid [91] and [92].
} 
considerations within the EU public procurement framework of rules and obligations. However, it suffices to note at this point that an alternative approach in striking this balance could also be envisaged. If measures that try to facilitate a response against forced labour can only be used as award criteria, this means that the use of these below-par practices become simply a consideration in the process of a cost and benefit analysis. Tenderers will continue to use them whenever it is beneficial for them from an economic point of view.

To be more precise, let us imagine that in a contract award, the criterion of price of the product corresponds to 70 per cent of the overall weighting and the criterion for the use of fair trade practices in the delivery of the product amounts to 15 per cent of the overall weighting. ${ }^{81}$ Let us also imagine that there are two tenderers: one that abides by high labour standards and one that uses forced labour abroad. The latter will be penalised in effect by 15 per cent in the overall weighting because it does not fulfil the fair trade award criterion. However, if the use of forced labour abroad means that the production costs will be significantly lower, enabling the tenderer to submit a much more competitive price, then there seems to be an incentive for the tenderer to continue - or even to increase - the use of these practices. In this case, the dissuasive power of the de facto penalisation of 15 per cent through the award criteria is minimal. Of course, the balance could be tipped if the contracting authority would assign a greater weighting to the fair trade award criterion. Furthermore, it is obvious that the inclusion of these fair trade considerations in the 'selection criteria' would carry a much stronger moral message to tenderers and would immediately change the cost and benefit analysis; those who do not abide to higher standards would not be able to participate in the procurement. However, as we saw before, the CJEU seems not to allow the use of these criteria at the selection stage because this approach could have the impact of limiting competition in the procurement market.

In the pre-accession environment, it would be possible for sufferers of forced labour to bring an action against an EU Member State for its failure to comply with its

\footnotetext{
${ }^{81}$ Let us assume that the remaining 15 per cent is linked with other award criteria such as time delivery etc.
} 
obligation under the ECHR to demonstrate due diligence (aiming at the prevention of wrongfulness taking place outside its territory), ${ }^{82}$ while complying with its EU obligations in the field of procurement, although, as already mentioned, due the Bosphorus jurisprudence, this might have limited chances of success unless it could be shown that the state enjoyed discretion in the way it implemented EU law. By contrast, in the post-accession environment, it would be theoretically possible for the same victims to also bring an action against the EU itself for failure to comply with its due diligence obligations as a result of legislative (content of the substantive rules on procurement that introduce limits) or judicial action (interpretation of these rules by the CJEU), hindering the use of an effective and available positive measure (fair trade policy as a precondition in procurement) against forced labour.

However, even if this pathway seems indirect or far-fetched because the CJEU's position could stand the scrutiny by Strasbourg since it allows in principle the use of fair trade criteria in procurement subject to what seems to be a 'reasonable' balance of proportionality, it is argued nevertheless that the accession of the EU to the ECHR may contribute to the strengthening of what could be termed as the process of 'moral subordination' of the rules of the internal market to those of human rights. It is exactly at this point where the accession of the EU to the ECHR may produce the more subtle effect, because it might assist the transformation of the hermeneutic paradigm that the CJEU uses when human rights are at stake. At present, the hermeneutic paradigm has as a starting point the protection of market freedoms ${ }^{83}$ based on the assumption that the role of the CJEU is primarily their protection-and human rights are seen as factors that could justify measures that prima facie constitute trade barriers. Despite the often deferential approach that the CJEU follows when human rights clash with economic freedoms, through a fairly flexible proportionality test, human rights considerations seem to be an 'add-on' in this hermeneutic paradigm. ${ }^{84}$ Although it is doubtful whether post-accession the new hermeneutic

\footnotetext{
${ }^{82}$ Ilaşcu and others v Moldova and Russia, App No 48787 (2004) 40 EHRR 1030 [331].

${ }^{83}$ As well as related rights deriving from secondary EU law such as those established in the area of public procurement.

${ }^{84}$ See, for example, Case C-438/05 International Transport Workers' Federation v Viking Line ABP [2007] ECR I-10779; Case C-341/05 Laval un Patneri v Svenska Byggnadsarbetareförbundet [2007] ECR I-11767.
} 
paradigm would entail a repositioning of human rights as the point of departure in the CJEU's evaluation (this will very much depend on the type of cases that would reach the CJEU), it can be argued that the function of the CJEU as a 'human rights court' would not be simply a welcome surprise, but an expectation. For example, in the field of procurement as in other areas of the internal market, the CJEU would perhaps be more susceptible to allow even more discretion to Member States to assess the effectiveness of the means they use to comply with their human rights obligations (including due diligence obligations). This could take place during the CJEU's assessment of the means used by Member States in the context of the examination of proportionality. Besides, post-accession, the subtle effect of this 'moral subordination, ${ }^{85}$ could be manifested in the area of procurement not only at the judicial level but also at the legislative level. ${ }^{86}$

\section{Conclusions}

The present chapter set out to answer the following questions; first, whether there are any points of intersection between the field of public procurement and of human rights in general; second, whether such intersections exist between the European public procurement regulatory framework and that of the ECHR in particular; and, third, if a future EU accession to the ECHR is likely to have any impact in the law and practice of EU public procurement.

First of all, the chapter demonstrated that despite there being a prima facie disjuncture between public procurement and human rights, there have been instances of interrelation between these two fields of law and policy for some time now. This interrelation is stronger when the notions of public procurement and human rights are

\footnotetext{
${ }^{85}$ The term 'moral subordination' does not necessarily insinuate a position of higher authority for human rights in the hierarchy of norms within the EU legal order. Instead, it refers to a qualitative change in the ethos of the EU-a process that started with the EU Charter of Fundamental Rights - as manifested in the workings of the EU courts and the EU legislator.

${ }^{86}$ For example, the proposal for the new public procurement Directive submitted by the European Commission contains in Article 55(3) a possible - but not compulsory - ground for exclusion of an economic operator for the infringement of the ILO Convention 29 concerning forced or compulsory labour. However, it seems that the final text after the 'trialogue' negotiation between the EU Parliament, the Council and the Commission may include some provisions against forced labour in the compulsory exclusions of Article 55(1).
} 
understood widely, but it also exists even when these notions are perceived more narrowly. Furthermore, the chapter tried to explain why in the European context, the area of public procurement appears to be more disconnected from human rights in comparison to other areas of economic law-for example, competition law-both at the level of legal scholarship and at the level of legal practice. It argued in particular that this seems to be attributable to the fact that the EU has an elaborate legal framework of substantive rules governing public procurement supported by a sophisticated system of judicial remedies. Using the field of EU competition law as a point of comparison, the chapter observed that the architecture and the dynamics of the public procurement enforcement system create different types of concerns from those detected in the context of EU competition law enforcement, thus leading to a more 'self-contained' legal framework.

The chapter then elucidated that certain, albeit indirect, pathways for interaction between the two legal frameworks already exist. However, these pathways - particularly in the form of protection of individual rights before the ECtHR - have not been used so far at least to a meaningful degree. The chapter then argued that the EU's accession to the ECHR is likely to create new pathways of interaction between public procurement and human rights and may even strengthen existing ones by rendering them more appealing. This development could be effected through the recalibration, as a result of the accession, of the vertical institutional structure at the apex of which the ECtHR will be positioned-even if this does not lead to a substantial change to the existing relation of 'working parity' that exists between the courts in Luxembourg and Strasbourg - but most importantly through a change of ethos within the EU legal order.

In particular, the chapter concluded that the accession could have two types of impact on the interaction between these two areas of law and policy: a direct, tangible one and a more indirect, subtler one. The tangible impact is linked with the new pathway of judicial protection that would allow individuals to bring complaints against the EU directly-in addition to the existing possibility of bringing claims against the Member States for conduct that originates in and gives effect to rules and practices established at the EU level, in cases where the Bosphorus presumption is not 
satisfied or where Member States have discretion in the implementation of EU policies.

On the other hand, the subtler impact of accession relates to the overall strengthening of the process of 'moral subordination' of the rules of economic freedoms to those of human rights. This change of ethos would first of all complete the transformation of the CJEU into a 'human rights court'. This process has already started through the jurisprudence of the CJEU and more recently through the entry into force of the Charter of Fundamental Rights of the EU, but it can be argued that, due to the limits and conditions of the scope of application of the latter, the aforementioned process of transformation is to a certain degree incomplete. The EU's accession to the ECHR would 'superimpose' the Convention rights as a legal but also as a moral comparator/point of reference in a more complete, holistic manner. This transformation would not leave the field of EU public procurement unaffected. Instead, the chapter considered that this change could be manifested in the field of procurement first of all at the judicial level through a possible transformation of the hermeneutic paradigm employed by the CJEU - that could perhaps allow more discretion to Member States when they choose the means for effecting their human rights obligations - and also at the legislative level by strengthening the role human rights considerations as a significant parameter that the European legislator ought to take into account. 